\title{
Triggering of the Bergman Cyclization by Photochemical Ring Contraction. Facile Cycloaromatization of Benzannulated Cyclodeca-3,7-diene-1,5-diynes
}

\author{
Grigori V. Karpov and Vladimir V. Popik \\ Department of Chemistry, the University of Georgia, Athens, GA 30602
}

\begin{abstract}

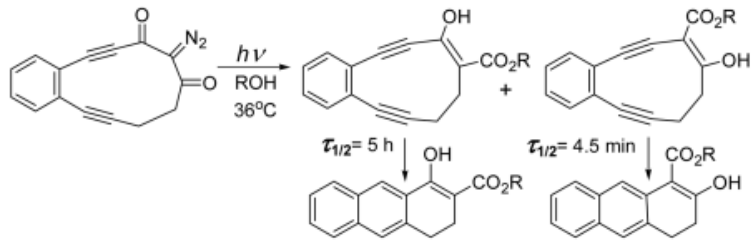

Eleven-membered ring enediyne 1, which incorporates $\alpha$-diazo- $\beta$-diketone moiety, undergoes efficient light-induced ring contraction to produce two isomeric ten-membered ring enediyne compounds. The latter undergo spontaneous facile Bergman cyclization at or below room temperature. In the photochemical or thermal Wolff rearrangement of $\mathbf{1}$ the alkyl substituent migrates ca. 2 times faster than the alkynyl group.
\end{abstract}

The extreme cytotoxicity of natural enediyne antibiotics is attributed to the ability of the (Z)-3ene-1,5-diyne fragment to undergo Bergman cyclization and produce DNA-damaging $p$ benzyne diradical. ${ }^{1,2}$ Photochemical triggering of this reaction allows for the spatial and temporal control of enediyne reactivity. Several examples of light-induced cycloaromatization of acyclic ${ }^{3,4}$ and cyclic ${ }^{5}$ enediynes, as well as of natural antibiotic Dynemicin $A,{ }^{6}$ have been reported in literature. Our group explores an alternative strategy of photoactivation: the in situ generation of a reactive enediyne system, which subsequently undergoes the cycloaromatization. ${ }^{7}$

Here we report the first example of triggering of the thermal Bergman cyclization by the photochemical ring contraction. The latter process causes substantial increase in the strain energy of cyclic enediynes thus triggering the cycloaromatization. It is known that elevenmembered ring enediynes are stable at ambient temperatures, while ten-membered analogs undergo spontaneous cyclization. ${ }^{8}$ We have designed and synthesized eleven-membered enediyne (1), which incorporates an $\alpha$-diazo- $\beta$-diketone moiety. Upon irradiation or thermolysis 1 undergoes Wolff rearrangement to produce reactive ten-membered enediynes 3a and 3b. The latter undergo spontaneous Bergman cyclization (Scheme 1).

The target 2-diazo-6,7-benzocycloundeca-4,8-diyn-1,3-dione (1) was prepared by the diazo transfer reaction from tosyl azide onto the $\beta$-diketone $\mathbf{1 4}$ (Scheme 2). ${ }^{9}$ The latter was in turn prepared by successive Dess-Martin oxidations of 1,3-diol 11. The crucial cyclization step has been achieved using the Nozaki-Hiyama-Kishi procedure (Scheme 2). ${ }^{10}$ 
The photo-Wolff reaction ${ }^{11}$ of diazodiketone 1 was expected to produce two isomeric $\beta$ ketoketenes $\mathbf{2 a}$ and $\mathbf{2 b}$, which should rapidly react with the hydroxylic solvents $\left(\tau_{\mathrm{H} 20} \sim 1\right.$ $\mu \mathrm{s})^{12}$ to give $\beta$-ketoesters $\mathbf{3 a}$ and $\mathbf{3 b}$ (Scheme 1).

In fact, the formation of characteristic ketene band at $2212 \mathrm{~cm}^{-1}$ in laser flash photolysis of $\mathbf{1}$ was detected by transient IR (TIR) spectroscopy. Ketenes $\mathbf{2 a}$ and $\mathbf{2 b}$, which are indistinguishable at the resolution of the TIR instrument, are formed within $30 \mathrm{~ns}$ after the laser pulse and decay with a life time of ca. $50 \mu$ s in the presence of $5 \%$ of methanol in $\mathrm{CCl}_{4}$. The $350 \mathrm{~nm}$ irradiation of 1 results in the efficient $\left(\Phi_{350}=0.36\right)$ dediazotization of the starting material. However, dihydroanthracene derivatives $\mathbf{4 a}(54 \%)$ and $\mathbf{4 b}(31 \%)$, as well as small amounts of diketone $14(<10 \%)$ were the only isolated products upon photolysis in 2-propanol $(\mathrm{R}=i-\mathrm{Pr}$, Scheme 1). $\mathbf{4} \mathbf{a}$ and $\mathbf{4 b}$ are the major products even at low conversion $(5-10 \%)$ of 1. Low temperature photolysis of $\mathbf{1}$ allowed us to isolate unstable ketoester $\mathbf{3 a}$, which predominantly exist in enol form ( $3^{\mathbf{E}} \mathbf{a}$, Scheme 3$)$. $\mathbf{3 a}$ undergoes clean cyclization to $\mathbf{4 a}$ with $\tau_{1 / 2}=5 \mathrm{~h}$ at $36^{\circ} \mathrm{C}$ in 2-propanol. However, enediyne $3 \mathbf{b}$ was not detected in the photolysate even at $0^{\circ} \mathrm{C}$. This observation allows us to conclude that enediyne and $\mathbf{3 b}$ is also formed in the photoWolff reaction of $\mathbf{1}$ but undergo rapid thermal Bergman cyclization to $\mathbf{4 b}$. The life time of enediyne $\mathbf{3 b}\left(\tau_{1 / 2}=4.5 \mathrm{~min}\right)$ was measured by following the growth of absorbance of $\mathbf{4 b}$ at 248 $\mathrm{nm}$.

The facile cycloaromatization of benzannulated ten-membered ring cyclic enediynes $\mathbf{3 a}, \mathbf{b}$, which resembles that of strained nine-membered C-1027 chromophore, ${ }^{13}$ is rather unusual. Other known derivatives of 3,4-benzocyclodeca-1,5-diyne (15, Scheme 3) are stable under ambient conditions and undergo slow Bergman cyclization only at elevated temperatures. ${ }^{14}$ NMR data indicate that ketoesters $\mathbf{3 a}$, and presumably $\mathbf{3 b}$, predominantly exist in the enol form (i.e., $3^{\mathbf{E}} \mathbf{a}$ and $3^{\mathbf{E}} \mathbf{b}$ correspondingly, Scheme 3). An additional endocyclic double bond apparently reduces the barrier for the Bergman cyclization. In fact, attempts to prepare 3,4-8,9dibenzocyclodeca-1,5-diyne produced only 5,12-dihydronaphthacene, ${ }^{15}$ while annulene $\mathbf{1 6}$ (Scheme 3), which can be generated photochemically or using flash vacuum pyrolysis, is a short-lived transient at room temperature ${ }^{16}$ and is relatively stable only in cryogenic matrixes. 17

The reactivity difference between regioisomeric enediynes $\mathbf{3 a}$ and $\mathbf{3 b}$ is also quite remarkable. We believe that this phenomenon is caused by the electronic influence of the substituent at the vinylic terminus of the $\pi$-conjugated system. Electron-rich hydroxyl group in $3^{\mathbf{E}} \mathbf{b}$ donates electron density to the out-of-plain $\pi$-orbitals thus increasing the aromatic stabilization of the Bergman cyclization transition state. ${ }^{18}$ The electron-withdrawing carbonyl group in $3^{\mathbf{E}} \mathbf{a}$, on the other hand, retards the cycloaromatization reaction.

In addition, the photochemistry of $\alpha$-diazo- $\beta$-diketone $\mathbf{1}$ provides us with the first direct experimental comparison of migratory aptitudes of $\mathrm{sp}^{3}$ and sp-hybridized carbon atoms in the Wolff rearrangement. $\beta$-Ketoesters $\mathbf{4 a}$ and $\mathbf{4 b}$, which are formed by the migration of alkyl and acetylenic substituents correspondingly, are obtained in the ratio of $7: 4$. This observation indicates the preferential migration of the alkyl versus alkynyl substituents in the Wolff rearrangement. Thermolysis of 1 at $100^{\circ} \mathrm{C}$ in ethanol in the presence of 1,4-cyclohexadiene produces $4 \mathbf{a}$ and $\mathbf{4 b}(\mathrm{R}=\mathrm{Et})$ in a similar ratio.

An initial evaluation of the DNA cleavage ability of photo-generated ten-membered ring enediynes $\mathbf{3 a}$ and $\mathbf{3 b}$ was carried out using supercoiled plasmid DNA cleavage assays. Three forms of this DNA: native (RF I), circular relaxed (RF II, produced by single-strand cleavage), and linear (RF III, formed by scission of both strand in close proximity) are readily separated by the agarose gel electrophoresis. 
Solutions containing various concentrations of 1 and $\varphi$ X174 supercoiled circular DNA (30 ng/ $\mu \mathrm{l})$ were irradiated at $351.1 \mathrm{~nm}$ using argon-ion laser at ca. $-5^{\circ} \mathrm{C}$. Diazodiketone $\mathbf{1}$ induces substantial single strand cleavage (RF II) of $\varphi$ X174 DNA upon irradiation, while linearized form (RF III) was observed only at higher concentrations of the cleaving agent $(>500 \mu \mathrm{M})$ and prolonged irradiation (Figure 1). The relatively high concentrations of $\mathbf{1}$, which are required to achieve double-strand DNA photoscission indicate that $\mathbf{1}$ has low affinity to a dDNA molecule. In order to improve the photonuclease activity of enediyne $\mathbf{1}$, it is being conjugated with a dDNA minor-groove binding moiety. It is also interesting to note that irradiation of $\mathbf{1}$ in the presence of $\varphi$ X174 produces a new modification of DNA with lowest electrophoretic mobility (Figure 1). The nature of this band, which was preliminarily attributed to the covalently cross-linked dimer, is under investigation.

In conclusion, the photoswitchable enediyne compound, which is stable in the dark but converted into a very reactive form by light-induced ring contraction, has been designed and synthesized. Benzannulated ten-membered ring enediynes containing an additional endocyclic double bond undergo facile cycloaromatization even at $0^{\circ} \mathrm{C}$. The electronic properties of substituents at the alkene termini of the extended $\pi$ - system have pronounced effect on the reactivity the dienediyne system.

\section{Supplementary Material}

Refer to Web version on PubMed Central for supplementary material.

\section{Acknowledgements}

Authors thank the NIH (CA91856-01A1) and the NSF (CHE-0449478) for the support of this project and Professor R.M. Wilson and Dr. E.T. Mack for the assistance in conducting DNA photocleavage experiments.

\section{References}

1. Bergman RG. Acc Chem Res 1973;6:25.

2. For recent reviews see: Enediyne Antibiotics as Antitumor AgentsBordersDBDoyleTWMarcel DekkerNew York1995Jones GB, Fouad FS. Curr Pharm Design 2002;8:2415.Nicolaou KC, Dai WM. Angew Chem, Int Ed Engl 1991;30:1387.Danishefsky SJ, Shair MD. J Org Chem 1996;61:16.

3. Kagan J, Wang X, Chen X, Lau KY, Batac IV, Tuveson RW, Hudson JB. J Photochem Photobiol, B 1993;21:135. [PubMed: 8301409]Turro NJ, Evenzahav A, Nicolaou KC. Tetrahedron Lett 1994;35:8089.Kaneko T, Takahashi M, Hirama M. Angew Chem, Int Ed Engl 1999;38:1267.Plourde G II, El-Shafey A, Fouad F, Purohit A, Jones G. Bioorg Med Chem Lett 2002;12:2985. [PubMed: 12270189]

4. Benites PJ, Holmberg RC, Rawat DS, Kraft BJ, Klein LJ, Peters DG, Thorp HH, Zaleski JM. J Am Chem Soc 2003;125:6434-46. [PubMed: 12785783]Kraft BJ, Coalter NL, Nath M, Clark AE, Siedle AR, Huffman JC, Zaleski JM. Inorg Chem 2003;42:1663. [PubMed: 12611537]

5. Choy N, Blanco B, Wen J, Krishan A, Russell KC. Org Lett 2000;2:3761. [PubMed: 11101413]Funk RL, Young ERR, Williams RM, Flanagan MF, Cecil TL. J Am Chem Soc 1996;118:3291.

6. Shiraki T, Sugiura Y. Biochemistry 1990;29:9795. [PubMed: 2271616]

7. Poloukhtine A, Popik VV. J Org Chem 2005;70:1297. [PubMed: 15704964]Poloukhtine A, Popik VV. Chem Comm 2005:617. [PubMed: 15672154]

8. Magnus P, Lewis RT, Huffmann JC. J Am Chem Soc 1988;110:6921.Schreiner PR. J Am Chem Soc 1998;120:4184.Cramer CJ. J Am Chem Soc 1998;120:6261.Koseki S, Fujimura Y, Hirama M. J Phys Chem A 1999;103:7672.Nicolaou KC, Ogawa Y, Zuccarello G, Schweiger EJ, Kumazawa T. J Am Chem Soc 1988;110:4866.Jones GB, Wright JM, Hynd G, Wyatt J, Warner PM, Huber RS, Li A, Kilgore MW, Sticca RP, Pollenz RS. J Org Chem 2002;67:5727. [PubMed: 12153275]

9. Supporting Information

10. Takai K, Kuroda T, Nakatsukasa S, Oshima K, Nozaki H. Tetrahedron Lett 1985;26:5585. 
11. For a recent review see: Kirmse W. Eur J Org Chem 2002:2193.

12. Chang JA, Kresge AJ, Nikolaev VA, Popik VV. J Am Chem Soc 2003;125:6478. [PubMed: 12785788] b) Chiang Y, Kresge AJ, Nikolaev VA, Popik VV. J Am Chem Soc 1997;19:11183.

13. Yoshida K, Minami Y, Otani T, Tada Yukio, Hirama M. Tetrahedron Lett 1994;35:5253.

14. Semmelhack MF, Neu T, Foubelo F. J Org Chem 1994;59:5038.

15. Henry NC, Sondheimer F. Tetrahedron Lett 1980;21:217.

16. Schottelius MJ, Chen P. J Am Chem Soc 1996;118:4896.

17. Wenk HH, Sander W. Eur J Org Chem 1999:57.

18. a) Alabugin IV, Manoharan M. J Phys Chem A 2003;107:3363. b) Schreiner PR, Navarro-Vasquez A, Prall M. Acc Chem Res 2005;38:29. [PubMed: 15654734] c) Rawat DS, Zaleski JM. Synlett 2004:393. 


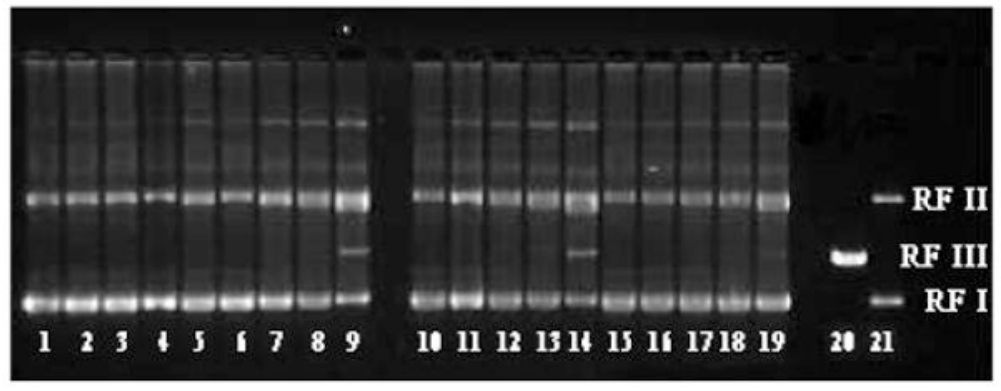

Figure 1.

Light induced cleavage of $\varphi$ X174 DNA in presence of 1. Lanes 1-5: DNA irradiated for 0, 15, 45, 180 and $480 \mathrm{~s}$; lanes 6-9: DNA + $1(1787 \mu \mathrm{M})$, irradiated for $0,15,45$ and $180 \mathrm{~s}$; lanes 10-14: DNA + $1(488 \mu \mathrm{M})$, irradiated for $0,15,45,180$ and $480 \mathrm{~s}$; lanes 15-19: DNA + 1 (82 $\mu \mathrm{M})$, irradiated for $0,15,45,180$ and $480 \mathrm{~s}$; lane 20: DNA incubated with PSt-I restriction enzyme for 1 hour at $37^{\circ} \mathrm{C}$; lane 21: DNA alone. 


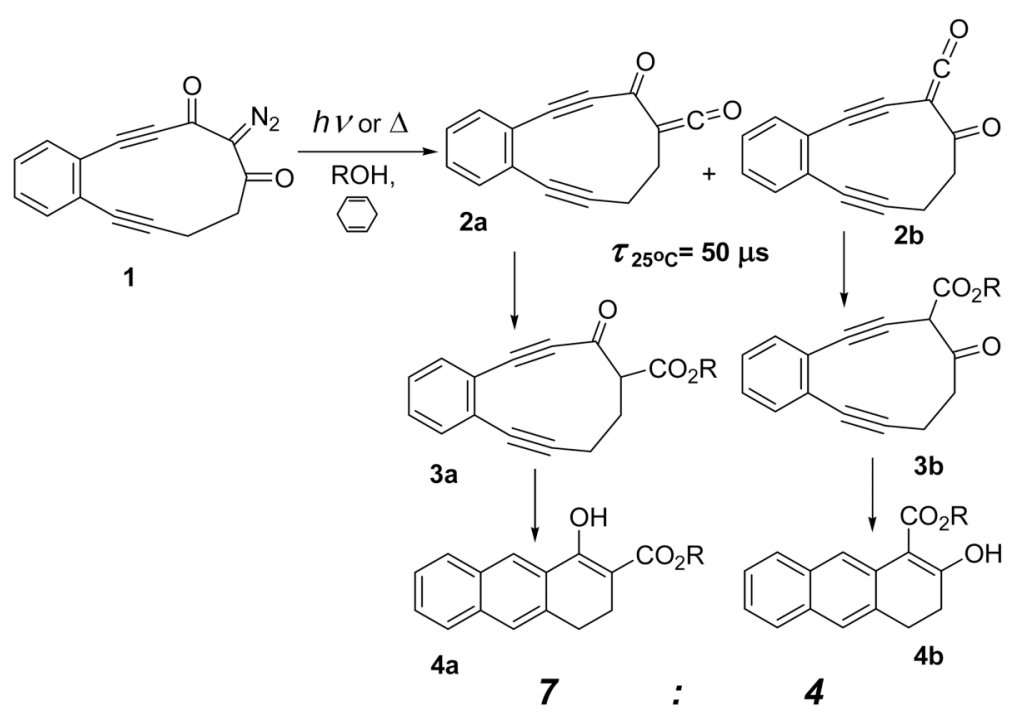

Scheme 1. 

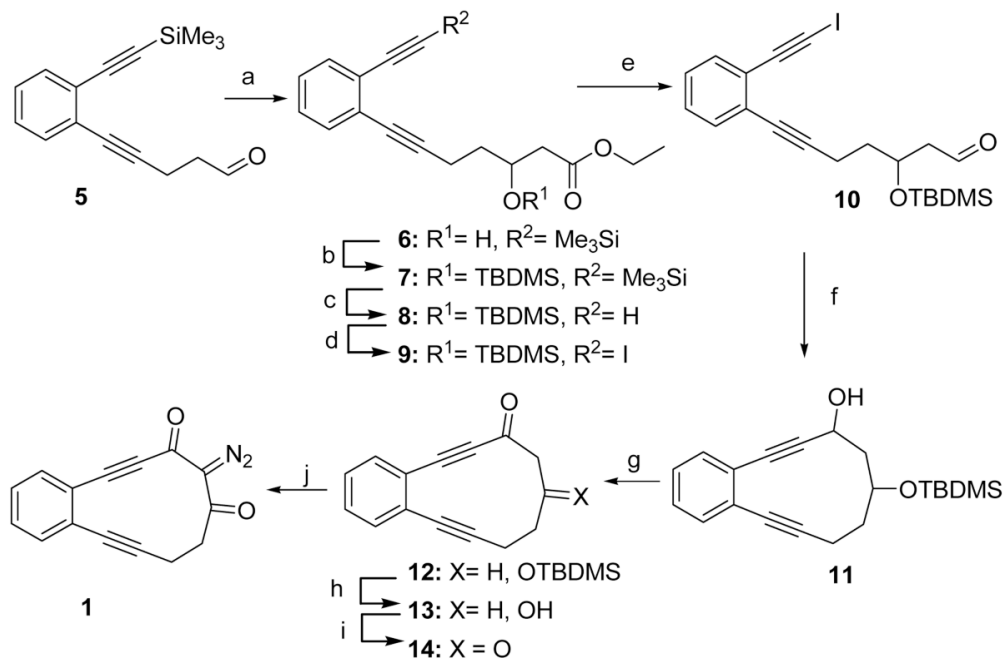

Scheme 2.

Synthesis of diazodiketone $1^{\text {a }}$

a Reagents and conditions: (a) LDA/EtOAc, 90\%; (b) TBDMS-Cl, Imidazole/DMAP, 90\%;

(c) $\mathrm{K}_{2} \mathrm{CO}_{3} / \mathrm{MeOH}, 97 \%$; (d) $\mathrm{I}_{2} /$ Morpholine, Benzene, $50^{\circ} \mathrm{C}, 91 \%$; (e) DIBAL, $91 \%$; (f) $\mathrm{CrCl}_{2} / \mathrm{NiCl}_{2}$, THF, 84\%; (g) Dess-Martin periodinane, 92\%; (h) HF, MeCN 88\%; (i) DessMartin periodinane, $84 \%$ (j) DBU, $\mathrm{TsN}_{3}, 84 \%$. 


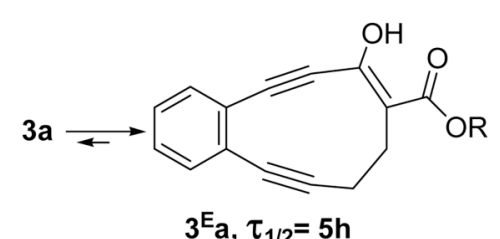

$3^{\mathrm{E}} \mathrm{a}, \tau_{1 / 2}=5 \mathrm{~h}$

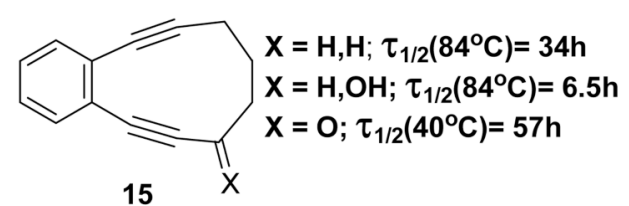

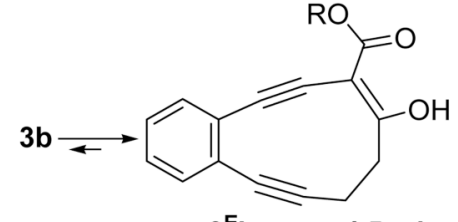

$3^{\mathrm{E}} \mathrm{b}, \tau_{1 / 2}=4.5 \mathrm{~min}$

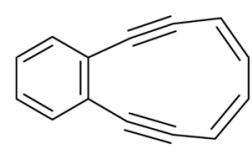

$16, \tau \sim 1 \mathrm{~ms}$

Scheme 3 . 